\title{
MINERALOGY AND ORGANIC MATTER CONTENT OF BOTTOM ASH SAMPLES FROM AGIOS DIMITRIOS POWER PLANT, GREECE
}

\author{
Kantiranis N., Georgakopoulos A., Filippidis A. and Drakoulis A. \\ Department of Mineralogy-Petrology-Economic Geology, School of Geology, Aristotle University \\ of Thessaloniki,54214,Thessaloniki, kantira@geo.auth.gr, ageorgak@geo.auth.gr, \\ anestis@geo.auth.gr, alexdr@geo.auth.gr
}

\section{ABSTRACT}

Four bottom ash samples from the Power Units of the Agios Dimitrios Power Plant were studied by the method of PXRD to determine their semi-quantitative mineralogical composition. Their organic matter content was calculated by a wet chemical process. Also, the loss on ignition was measured. The samples are constituted mainly of calcite, quartz and feldspars, while micas, clays, gehlenite and portlandite were determined in a few samples in smaller quantities. The amorphous material varied between 10-43 wt. \%, while organic matter varied between 5-42 wt. \%. Measurements of the loss on ignition overestimate the unburned lignite contents in the bottom ash samples. The management of bottom ashes with high contents of unburned lignite should differ to that of the fly ashes. The oxidation of the inorganic compounds of the unburned lignite may lead to environmental degradation of the landfill areas. Samples showing lower values of organic matter are suitable for a series of uses, such as: snow and ice control, as an aggregate in lightweight concrete masonry units, as a raw feed material for portland cement, as an aggregate in cold mix emulsified asphalt mixes, base or sub-base courses, or in shoulder construction. Systematic study of the unburned lignite of bottom ashes is needed for possible re-combustion.

\section{INTRODUCTION}

More than $73 \%$ of the electrical power requirements of Greece are generated by coal-fired power plants. The main coal mining area in Greece is the Lignite Center of Western Macedonia in the Ptolemais-Amynteo region of Northern Greece. The lignites exploited in the opencast mines are used to generate electricity in the power plants of Liptol (43 MW), Amynteo-Filotas (600 MW), Ptolemais (620 MW), Kardia (1200 MW), Agios Dimitrios (1585 MW) and Florina (330 MW). The Greek Power Plants consume approximately 65 million tons of lignite per year. In the Lignite Center of Western Macedonia, lignite is mined from four big mines, the biggest one being the Southern Field Mine, with an annual production of 24 million tons of lignite (Kolovos et al., 2002). The Southern Field Mine feeds the Agios Dimitrios Power Plant, a typical steam generating Power Plant, the largest in Greece, with a total installed capacity of $1585 \mathrm{MW}$ in five lignite thermal units $(2 \times 300 \mathrm{MW}$, $2 \times 310 \mathrm{MW}, 1 \times 365 \mathrm{MW}$ ) producing $29 \%$ of Greece's total thermal electricity power. The coal is pulverized and blown into a burning chamber where it immediately ignites; the incombustible portion of this material not collected in the flue, as fly ash, is known as dry bottom ash, which drops down into a water-filled hopper at the bottom of the boiler. The amount of bottom ash does not exceed $2 \%$ of the solid wastes produced. Fuel burning also produces flue gases that can only be disposed into the environment. Bottom ash is a coarse, angular material of porous surface texture and ranges from fine gravel to fine sand in size and is predominantly sand-sized (Rogbeck and Knutz, 1996; Ceriaf et al., 1999; Baba, 2002). Due to the inherent salt and heavy metal content and in some cases low pH this material may exhibit corrosive and toxic properties (Roth at al., 1983; Thuß et al., 1997; Wang et al., 1999; Goodarzi and Huggins 2001). This material is highly susceptible to degradation under compaction and loading; as a result, bottom ash is not an acceptable aggregate for most highway construction applications. Bottom ash can be used as a soil amendment (Sell et al., 1989), for snow and ice control, as an aggregate in lightweight concrete masonry units, and as a 
raw feed material for portland cement (Rogbeck and Knutz, 1996; Kula et al., 2001; Targan et al., 2002, 2003; Canpolat et al., 2003). This material has also been utilized as an aggregate in cold mix emulsified asphalt mixes, base or sub-base courses, or in shoulder construction, where gradation and durability requirements are not as critical (Rogbeck and Knutz 1996; Schreurs et al., 2000; Zeng and Ksaibati 2003). In the USA four states have recently made use of bottom ash as a granular base material and 0.7 million tons of bottom ash were used as road base or sub-base material (American Coal Ash Association, 1996). The quality of the material depends upon how the material was stockpiled before use. Bottom ash may require stockpiling for a short period of time (at least 1 or 2 days) to allow excess water to drain. Fly ash, another byproduct of coal-fired plants, has already found a market.

In the present study the properties of bottom ash samples from four Power Units of the Agios Dimitrios Power Plant are examined including their mineralogical composition and their unburned lignite and amorphous content. In another Power Station of the Lignite Center of Western Macedonia, the Ptolemais Power Plant, in order to improve the removal of bottom ash on Unit 4, Public Power Corporation of Greece decided to replace the existing ash-removal system with a drybottom-ash system manufactured by the Italian company Magaldi. This new system is able to remove the unit's bottom ash without using water for cooling the ash or conveying. The ash is recycled into the boiler to burn unburned material (lignite). There was no increase in either bottom ash or fly ash from this. This resulted in a saving of lignite, while ash recycling means that there is no waste bottom ash produced (Vlachos and Carrea, 1996).

\section{MATERIALS AND METHODS}

In the Power Plants of Northern Greece the bottom ash falls from the furnace into a water basin located beneath the boiler and is extracted by a submerged chain conveyor. Spot wet bottom ash samples, each one weighing about $2 \mathrm{Kg}$, were collected from four Power Units of the Agios Dimitrios Power Plant (Units I, II, IV and V), Power Unit III being out of use at the time of sampling. The samples were air-dried at room temperature and then ground by hand in an agate mortar to a fragment size of $<63 \mu \mathrm{m}$ in order to determine the semi-quantitative mineralogical composition and the contained organic matter.

Powder X-ray diffraction (PXRD) was performed using a Philips PW 1710 diffractometer with Nifiltered $\mathrm{CuK}_{\alpha}$ radiation on randomly oriented samples. The samples were scanned over the interval $3-63^{\circ} 2 \theta$ at a scanning speed of $1.2^{\circ} / \mathrm{min}$. The characterization of the mineral phases was performed semi-quantitatively on the basis of the intensity (counts) of specific reflections (calcite 3.03 $\AA$, quartz $3.34 \AA$, micas-mainly muscovite $9.97 \AA$, clays-mainly kaolinite $7.14 \AA$, feldspars-mainly albite $3.18 \AA$, gehlenite $2.84 \AA$ and portlandite $2.63 \AA$ ), the density and the mass absorption coefficient $\left(\mathrm{CuK}_{\mathrm{a}}\right)$ of the identified mineral phases. The organic matter and the inorganic amorphous material formed during the lignite combustion are both represented by a broad background hump starting at $\sim 10^{\circ} 2 \theta$ in the PXRD patterns. The semi-quantitative estimation of the percentage of total amorphous material was achieved by comparing the area of each broad background hump which represented the amorphous material in each sample with the analogous area of standard mixtures of minerals with different contents of natural amorphous material (Kantiranis et al., 1999; Kantiranis et al., 2004) scanned under the same conditions. According to Kantiranis et al. (2004) the PXRD method is a very good, effective and useful tool for the determination of the percentage of amorphous material contained in a natural or synthetic sample.

Measurement of the organic matter contained in the samples was achieved by oxidation of the carbon by the addition of excess $1 \mathrm{~N} \mathrm{~K}_{2} \mathrm{Cr}_{2} \mathrm{O}_{7}$ (Alexiadis, 1972). 0.1-0.5 $\mathrm{g}$ of ground sample was added to a $250 \mathrm{ml}$ conical flask along with $10 \mathrm{ml} 1 \mathrm{~N} \mathrm{~K}_{2} \mathrm{Cr}_{2} \mathrm{O}_{7}$ and the mixture was stirred. $20 \mathrm{ml}$ of $\mathrm{H}_{2} \mathrm{SO}_{4}(>95 \%)$ was then added using a burette, taking care to ensure no sample was retained on the sides of the flask. To allow full oxidation of the carbon the flask was placed on a magnetic stirrer-plate and stirred for a further 20-30 minutes. Deionized water $(200 \mathrm{ml}), 10 \mathrm{ml} \mathrm{H}_{3} \mathrm{PO}_{4}, 0.2 \mathrm{~g} \mathrm{NaF}$ and $1-2 \mathrm{ml}$ of the indicator 1.10 phenanthroline were subsequently added. Then, the remaining $\mathrm{K}_{2} \mathrm{Cr}_{2} \mathrm{O}_{7}$ was titrated with $0.5 \mathrm{~N} \mathrm{FeSO}_{4}$. A color change from olive-green to blue-green indicated the end-point of the titration. The amount of organic matter was calculated using the following equation: 


$$
\text { Organic matter }=\left(1-\frac{V_{1}}{V_{0}}\right) \times \frac{6.7236}{M},(w t \%)
$$

$\mathrm{V}_{\mathrm{o}}$ is the volume $(\mathrm{ml})$ of the $0.5 \mathrm{~N} \mathrm{FeSO}_{4}$ required to neutralize $10 \mathrm{ml}$ of $1 \mathrm{~N} \mathrm{~K}_{2} \mathrm{Cr}_{2} \mathrm{O}_{7}, \mathrm{~V}_{1}$ is the volume $(\mathrm{ml})$ of $0.5 \mathrm{~N} \mathrm{FeSO}_{4}$ required to titrate the excess $\mathrm{K}_{2} \mathrm{Cr}_{2} \mathrm{O}_{7}$ and $\mathrm{M}$ is the sample's weight $(\mathrm{g})$.

The loss on ignition (L.O.I.) of the studied samples was determined by heating at $1050^{\circ} \mathrm{C}$ for $120 \mathrm{~min}$. The weight difference of the sample before and after heating, expressed as a \% percentage, represents the sample L.O.I.

\section{RESULTS AND DISCUSSION}

The results of the semi-quantitative mineralogical composition (wt. \%) of the studied samples along with their percentage of organic matter (wt. \%) and loss on ignition (wt. \%) are shown in Table 1. Also, in Fig. 1 the PXRD patterns of the studied bottom ash samples are shown.

Table 1. Semi-quantitative mineralogical composition (wt. \%), organic matter (wt. \%) and loss on ignition of the bottom ash samples studied.

\begin{tabular}{lccccccccc|ccc}
\hline Unit & C & Q & M & Cl & F & G & P & A & Total & OM & I.A.M. (A-OM) & L.O.I. \\
\hline I & 32 & 20 & - & 2 & 3 & - & - & 43 & 100 & 42 & 1 & 49 \\
II & 29 & 23 & 2 & - & 6 & 5 & - & 35 & 100 & 33 & 2 & 39 \\
IV & 25 & 23 & - & - & 21 & 8 & 10 & 13 & 100 & 6 & 7 & 12 \\
V & 20 & 34 & - & - & 11 & 7 & 18 & 10 & 100 & 5 & 5 & 10 \\
\hline
\end{tabular}

C: calcite, Q: quartz, M: micas, Cl: clays (kaolinite), F: feldspars, G: gehlenite, P: portlandite, A: total amorphous material (determined by PXRD, including organic matter), OM: organic matter (determined by net chemical method), IAM: inorganic amorphous material, L.O.I.: loss of ignition at $1050^{\circ} \mathrm{C} / 2 \mathrm{~h}$.

Silicates, carbonates, clays, sulfates and oxides dominate the mineral matter in coals (Ward, 1984; Swaine, 1990; Filippidis et al., 1996). During coal combustion the mineral matter of coal undergoes a series of physical and chemical changes (Georgakopoulos et al., 1994; Filippidis et al., 1996). The major mineral phases detected in the different bottom ash samples from Agios Dimitrios Power Plant were: calcite (20-32 wt. \%), quartz (20-34 wt. \%) and feldspars (3-21 wt. \%), while in some samples micas ( 2 wt. \% in bottom ash sample of Unit II), clays ( 2 wt. \% in bottom ash sample of Unit I), gehlenite (5-8 wt. \% in bottom ash samples of Units II,IV,V) and portlandite (10 and 18 wt. $\%$ in Units IV and V, respectively) were also determined. Some minerals contained in the bottom ash (calcite, quartz, micas, and clays) were initial constituents of the mined lignite, while others (gehlenite and portlandite) were formed during the combustion of the lignite. In particular portlandite was formed on the hydration of quicklime, derived from the thermal decomposition of calcite (Oates 1998; Filippidis and Georgakopoulos 1992; Kantiranis 2001, 2003), by the soaking of bottom ash with water during its transportation from the Power Units to the lignite disposal areas.

The total amorphous material varies between 10 and 43 wt. \% with higher percentages determined for Units I and II (43 and 35 wt. \%, respectively). It consists of the organic content of the bottom ash and the inorganic amorphous material formed during lignite combustion. The percentage of organic matter determined by the wet chemical method, varies between 5-42 wt. \%. Once again higher percentages are determined for Units I and II (42 and 33 wt. \% respectively). The inorganic amorphous material (=total amorphous material-organic matter) varies between 1-7 wt. \%.

Until now, loss on ignition has been used as an indicator for the evaluation of the percentage of unburned lignite in a bottom ash sample. L.O.I. measured in the samples examined varies between 10 and 49 wt. \%, with higher values observed in bottom ash from the Power Units I and II (49 and 39 wt. \%, respectively). There is an important difference (5-7 wt. \%) between the values of organic matter calculated by the wet chemical method and those calculated from the L.O.I. The loss on ignition of a bottom ash sample is a complex parameter and owed not only to the combustion of the unburned lignite, but also to the thermal decomposition of calcite and the dehydration of portlandite and sheet silicate minerals. 

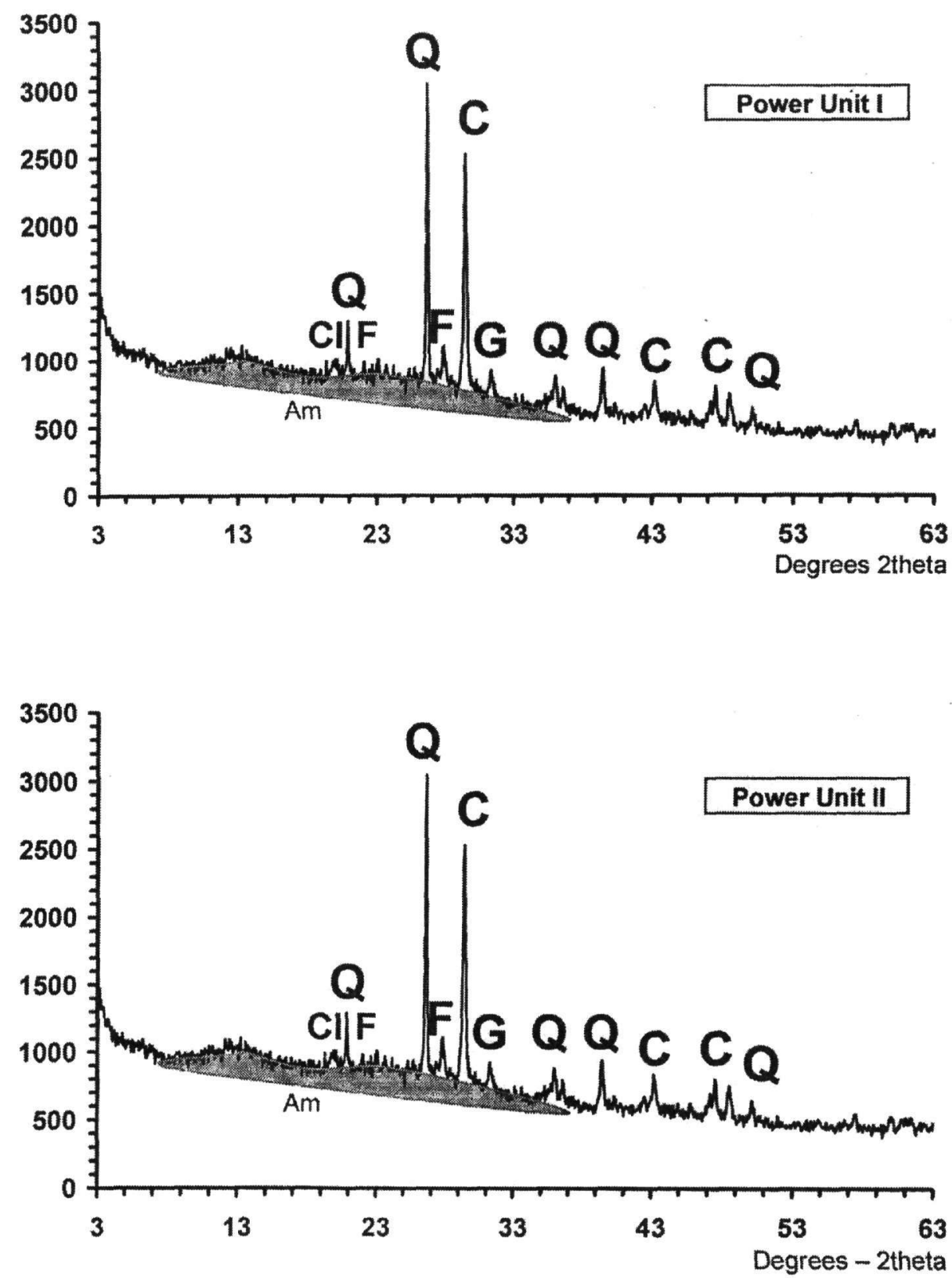

Figure 1. PXRD patterns of the bottom ash samples from the Power Units I and II (Symbols as in Table 1). 

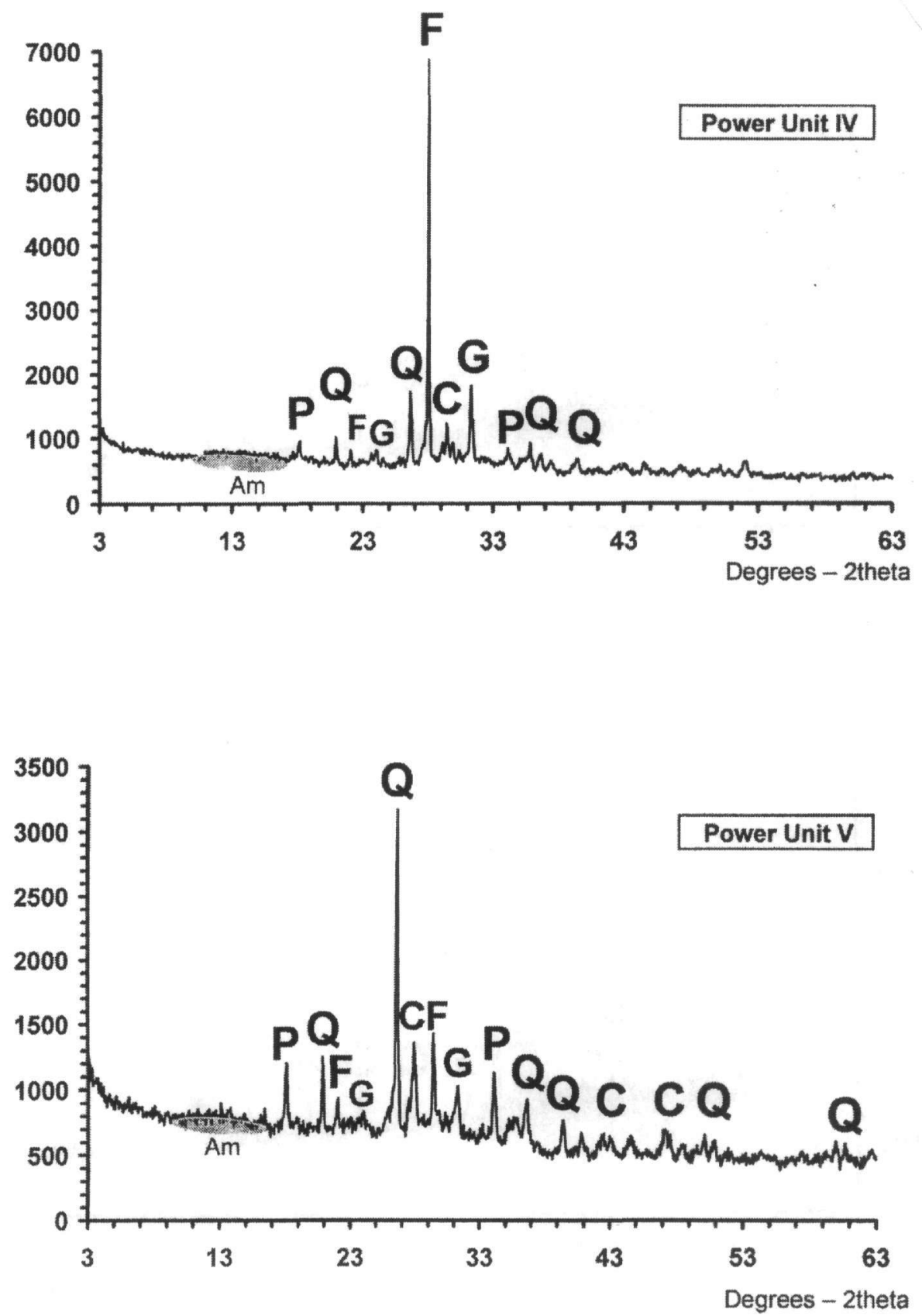

Figure 2. PXRD patterns of the bottom ash samples from the Power Units IV and V (Symbols as in Table 1).

According to the Public Power Corporation of Greece the percentage of bottom ash varies between $0.5-2$ wt. \% of the total solid wastes produced. The presence of a high percentage of organic matter (which represents a high percentage of unburned lignite) in spot samples from Power Units I and II of the Power Plant of Agios Dimitrios, reveals probable operation problems at the given time for the particular Units. Bottom ash from Units I and II, having high percentages of unburned lignite, could be recycled into the boiler to burn the unburned material. 
The removal and rejection of the quantities of bottom ash with high organic matter content and their management as fly ash is likely to pose a high environmental risk. The oxidation of the inorganic compounds of the unburned lignite may lead to environmental degradation of the landfill areas (such as self-combustion, leaching of elements etc.). Also, the high content of organic matter renders the particular bottom ash as useless for almost all the purposed uses.

The bottom ashes from Units IV and V have low percentages of organic matter (coal) and all their mineralogical characteristics indicate that they may be managed as fly ash. They are suitable for a series of uses, such as: snow and ice control, as an aggregate in lightweight concrete masonry units, and as a raw feed material for portland cement. This material has also been utilized as an aggregate in cold mix emulsified asphalt mixes, base or sub-base courses, or in shoulder construction.

\section{CONCLUSIONS}

Measurements of the loss of ignition overestimate the unburned lignite contents in the bottom ash samples.

Bottom ash samples from Power Units I, II, IV and V of Agios Dimitrios Power Plant show completely different mineralogical characteristics and organic matter contents. Samples from Power Units I and II have high percentages of organic matter (43 and $33 \mathrm{wt}$. \%, respectively) and are proposed for re-combustion with the feeding lignite. The management of bottom ashes with high contents of unburned lignite should differ to that of the fly ashes. The oxidation of the inorganic compounds of the unburned lignite may lead to environmental degradation of the landfill areas (selfcombustion, leaching of elements).

Samples from Power Units IV and V show distinctly lower values of organic matter content (6 and $5 \mathrm{wt}$. \%, respectively) and all the mineralogical characteristics allow their management as fly ash. They are suitable for a series of construction and environmental uses. Systematic study of the unburned lignite of bottom ashes is needed to assess if they are suitable for re-combustion.

\section{REFERENCES}

Alexiadis, A., 1972. Physical and chemical analysis of soil, Thessaloniki, University Publications, 383pp.

American Coal Ash Association, 1996. Coal Combustion By-Product Production and Use: 1966-1994. Alexandria, Virginia.

Baba, A., 2002. Assessment of radioactive contaminants in by-products from Yatagan (Mugla, Turkey) coal-fired power plant, Environmental Geology 41, 916-921.

Canpolat, F., Yilmaz, K., Köse, M.M., Sümer, M., and Yurdusev, M.A., 2003. Use of zeolite, coal bottom ash and fly ash as replacement materials in cement production, Cement and Concrete Research 23-24, 1-5.

Cherial, M., Cavalcante Rocha, J., and Péra, J., 1999. Pozzolanic properties of pulverized coal combustion bottom ash, Cement and Concrete Research 29, 1387-1391.

Filippidis, A., and Georgakopoulos, A., 1992. Mineralogical and chemical investigation of fly ash from the Main and Northern lignite fields in Ptolemais, Greece. Fuel 71(4), 373-376.

Filippidis, A., Georgakopoulos, A., Kassoli-Fournaraki, A., 1996. Mineralogical components of some thermally decomposed lignite and lignite ash from the Ptolemais basin, Greece. International Journal of Coal Geology 30, 303-314.

Georgakopoulos, A., Filippidis, A., Kassoli-Fournaraki, A., 1994. Morphology and trace element contents of the fly ash from Main and Northern lignite fields, Ptolemais, Greece. Fuel 73(11), 1802-1804.

Goodarzi, F., and Huggins F.E., 2001. Monitoring the species of arsenic, chromium and nickel in milled coal, bottom ash and fly ash from a pulverized coal-fired power plant in western Canada, Journal of Environmental Monitoring 3, 1-6.

Kantiranis, N., Tsirambides, A., Filippidis, A., and Christaras, B., 1999. Technological characteristics of the calcined limestone from Agios Panteleimonas, Macedonia, Greece. Materials \& Structures, 32, 546-551.

Kantiranis, N., 2001. Calcination study of the crystalline limestone from Agios Panteleimonas, Florina, Greece. PhD Thesis, School of Geology, Aristotle University of Thessaloniki, 196 p. (in Greek with extensive English summary).

Kantiranis, N., 2003. Hydration of high-calcium quicklime with methanol-water mixtures. Construction and Building Materials 17, 91-96. 
Kantiranis, N., Stergiou A., Filippidis A., Drakoulis, A., 2004. Evaluation of the percentage of the amorphous material using PXRD patterns. $10^{\text {th }}$ Int. Congress of the Geological Society of Greece, Thessaloniki, April 1417, $89-90$ (in Greek).

Kolovos, N. Georgakopoulos, A. Filippidis, A., and Kavouridis, C., 2002. The effects on the mined lignite quality characteristics by the intercalated thin layers of carbonates in Ptolemais Mines, Northern Greece, Energy Sources 24, 761-772.

Kula, I., Olgun, A., Erdogan, Y., and Sevinc, V., 2001. Effects of colemanite waste, coal bottom ash, and fly ash on the properties of cement, Cement and Concrete Research 31, 491-494.

Oates, J., 1998. Lime and limestone, chemistry and technology, production and uses, Weinheim, Willey-VCH, $455 p p$.

Rogbeck, J., and Knutz, 1996. Coal bottom ash as light fill material in construction, Waste Management 16, 125-128.

Roth, J.A., Debelak, K.A., and Feather, K.F., 1983. Removal rate of zinc from coal bottom ash in aqueous solutions, Water Research 17/9, 1139-1143.

Schreurs, J.P.G.M., van der Sloot, H.A., and Hendriks, Ch., 2000. Verification of laboratory-field leaching behavior of coal fly ash and MSWI bottom ash as a road base material, Waste Management 20, $193-201$.

Sell, N., Mclntosh, T., Severance, C., and Peterson, A., 1989. The agronomic land spreading of coal bottom ash: Using a regulated solid waste as a resource, Resourses, Conservation and Recycling 2/2, $119-129$.

Swaine, J.D., 1990. Trace elements in coal, London, Buttrworths.

Targan, Ş., Olgun, A., Erdogan, Y., and Sevinc, V., 2002. Effects of supplementary cementing materials on the properties of cement and concrete, Cement and Concrete Research 32, 1551-1558.

Targan, Ş., Olgun, A., Erdogan, Y., and Sevinc, V., 2003. Influence of natural pozzolan, colemanite ore waste, bottom ash, and fly ash on the properties of Portland cement, Cement and Concrete Research 33, 11751182.

Thuß, U., Herzschuh, R., Popp, P., Ehrlich, Chr., and Kalkoff, W.-D., 1997. PCDD/F in flue gas and in bottom ash of lignite domestic combustion and the role of the salt content of the burned briquettes, Chemosphere 34, 1091-1103.

Vlachos, S., and Carrea, A., 1996. Dry-ash system retrofit improves efficiency of Unit 4 at Ptolemais Power Station, Power Engineering International 4(3), 41-43.

Wang, Y., Ren, D., and Zhao, F., 1999. Comparative leaching experiments for trace elements in raw coal, laboratory ash, fly ash and bottom ash, International Journal of Coal Geology 40, 103-108.

Ward, C.R., 1984. Coal Petrology and coal technology, London, Blackwell.

Zeng, M., and Ksaibati, K., 2003. Evaluation of moisture susceptibility of asphalt mixtures containing bottom ash, Transportation Research Record 1832, 25-33. 